ANNA FILIPCZAK-Kocur

(Opole)

\title{
Informacje o sejmach $i$ sejmikach w korespondencji Sapiehów \\ w Centralnym Państwowym Historycznym Archiwum w Kijowie
}

\author{
Informationen über Parlamente und Landtage \\ in der Korrespondenz der Familie Sapieha \\ im Zentralstaatsarchiv für Geschichte der Ukraine von Kiev
}

1. Informacje o sejmach w przekazach epistolarnych. 2. Leon Sapieha do syna z sejmu $1620 \mathrm{r}$.

3. Krzysztof Zawisza o sejmie warszawskim 1626 r. 4. Andrzej Zawisza o sejmie 1629 r.

5. Opinie Stefana Paca o przebiegu sejmu 1638 r. 6. Informacje o konwokacjach litewskich i sejmikach.

1. Informationen über Reichstage in Briefen. 2. Leon Sapiehas Korrespondenz an seinen Sohn vom Parlamenten 1620. 3. Krzysztof Zawisza über das Warschauer Parlament 1626. 4. Andrzej Zawisza über das Parlament 1629. 5. Verlauf des Parlament 1638 aus der Sicht von Stefan Pac. 6. Information über litauiche Einberufungen und Landtage.

Zespół ten liczy 1052 jednostki z lat $1402-1831$ i pochodzi z Dereczyna ${ }^{1}$. Najciekawsze informacje w sprawach sejmowych znalazlam w korespondencji Leona Sapiehy oraz Krzysztofa Zawiszy do Jana Stanisława Sapiehy, a dotyczą one sejmów $z$ lat 1620, 1626 (zwyczajnego), 1629 (zwyczajnego) oraz 1638. Korespondencja ta nie byla do tej pory wykorzystana przez autorów biografii trzech pierwszych sejmów.

\section{2}

Jan Stanisław Sapieha był synem Leona; w 1617 r. został marszałkiem nadwornym, w 1621 r. marszałkiem wielkim litewskim. Nie był obecny na

${ }^{1}$ Centralne Państwowe Historyczne Archiwum Ukrainy w Kijowie [dalej: CPHAUK] F. 48; A. R a chu b a, Archiwa Sapiehów - ich losy i stan obecny, Miscellanea Historico-Archivistica 1998 , t. IX, s. 105. 
sejmie odbywającym się pod wrażeniem klęski cecorskiej (3 XI-11 XII 1620 r.), ale byl informowany o obradach, między innymi przez swego ojca Leona Sapiehę. Pierwszy list datowany jest na 15 września ${ }^{2}$, czyli dziesięć dni od rozpoczęcia sejmu. Była to niedziela upamiętniona zamachem na życie Zygmunta III, ale informacja o tym znalazła się dopiero na końcu listu ${ }^{3}$.

Leon Sapieha pisal, że posłowie slabq obrone radza, tak jakoby to nas dotyczyć nie mialo. Posłowie, zwłaszcza krakowscy i sandomierscy, uparli się wymóc na królu, aby wyprawił na Ukrainę de suo 1000, a przynajmniej 600 ludzi. Kosztami wyprawy starali się obciążyć także duchowieństwo. Proponowano, aby arcybiskup gnieźnieński, Jan Wężyle i biskup krakowski, Marcin Szyszkowski wyprawili po 300 ludzi, inni biskupi - po 200,100 lub kilkudziesięciu. Duchowni oczywiście bronili się przed takim obciążeniem, ale ostatecznie zadeklarowali: arcybiskup gnieźnieński - 100 konnych i 50 pieszych, biskup krakowski - 100-150 piechoty oraz 50 konnych. Leon odradzał synowi wystawienia licznego pocztu $\mathrm{z}$ uwagi na wysokie koszty. Do każdej roty trzeba dołożyć: porucznika kontentować, darować, towarzystwo częstować. Przypomniał ciążący jemu samemu dług "moskiewski" 150 tys. zl. Ksiażęta Zbarascy, chociaż wielcy panowie, majacy wiele od króla, wystawiaja tylko 200 jazdy kozackiej oraz 200 piechoty - pisal4. Obaj książęta uważali się za pomijanych przez króla w nadaniach dobór i urzędów; mieli o to żal do monarchy. Jednak inaczej postrzegali to inni.

Kiedy kanclerz dowiedział się o decyzji syna wystawienia 200 kopijników, 200 piechoty i 100 jazdy kozackiej, wyraził dezaprobatę. W końcu napisał, że posłowie wycisnęli na senatorach duchownych i świeckich te poczty. On sam też obiecal wystawić 100 kozaków i 100 piechoty 5 .

Drugi problem, o którym kanclerz informował syna, to skrócenie sejmu do trzech tygodni. Wyrażal przy tym powątpiewanie, by było to możliwe. Sejm trwał już prawie dwa tygodnie, a jeszcze niczego nie postanowiono. Jednak nieliczni tylko chcieli, aby obradował sześć tygodni. Sapieha odniósł jednak wrażenie, że nie skończy się przed upływem przewidzianego czasu, chociaż zaraza zbierała już ofiary na Pradze. Leon bał się o syna, odradzał mu przyjazdu do Warszawy. W końcu listopada (27) okazało się, że wszyscy zgodzili się na skrócenie sejmu, a nawet o to prosili, oprócz braci Zbaraskich

${ }^{2}$ Leon Sapieha, kanclerz wielki litewski, do Jana Stanisława Sapiehy, marszałka nadwornego litewskiego, 15 X 1620 r. z Warszawy; CPHAUK, F. 48, op. 1, $\mathrm{nr} 800$.

${ }^{3}$ Informacja jest krótka, że Piekarski - brat pani wielkorządczyni krakowskiej Domaszewskiej starszej, targnął się czekanem na króla, gdy wchodził o godzinie 8 do kościoła św. Jana. Ludzie wpadli w panikę i zaczęli uciekać $z$ miasta, sądząc, że Tatarzy na króla napadli i zabili go. W liście z 30 listopada (ibidem, nr 802), Lew pisał o straceniu Piekarskiego.

${ }^{4}$ Potwierdzają to także inne źródła (J. Pi et rzak, Po Cecorze i podczas wojny chocimskiej. Sejmy z lat 1620 i 1621, Wrocław 1983, s. 61). Książęta Zabarascy przedstawili projekt walki z Tatarami i zaproponowali liczebność pocztów (loc. cit.).

${ }^{5}$ L. Sapieha do J. S. Sapiehy 27 XI 1620 r. z Warszawy, CPHAUK, F. 48, op. 1, nr 801. 
oraz kilku posłów $\mathrm{z}$ województw krakowskiego i sandomierskiego ${ }^{6}$. Kanclerz przypuszczal, że w tym tygodniu skończy się sejm, bo wybrano już deputację do konstytucji z koła poselskiego'. Tak się jednak nie stało; sejm dalej obradował, a Lew pisal o oziębłości wielkiej do ratunku i obrony. Niemniej 30 listopada mógł poinformować syna o uchwaleniu 8 lanowych, kwarty z Wielkiego Księstwa oraz innych niewymienionych podatków ${ }^{8}$.

Interesująca jest ponadto reakcja na wieść o porażce wojska polskiego w okolicach Cecory. Jeszcze 15 listopada pisał kanclerz, że pan Żólkiewski pewnie zabit, a 30 listopada: ...ludzie wierzyć nie chca, żeby wojsko z p. hetmanem zginqć mialo. W Warszawie wiedziano jednak już o przewiezieniu ciała hetmana bez ręki i bez glowy do Baru, o osobach wziętych do niewoli, m.in. o Lukaszu Żółkiewskim. Wiedziano w Warszawie o przygotowaniach tureckich do wojny. Leon Sapieha pisal o przyprowadzeniu cesarzowi tureckiemu 6 tys. wielbłądów oraz mnóstwa koni z Azji, które gromadzono na polach dobrudżskich, o sprowadzeniu dział używanych przeciwko Persji do Konstantynopola. Znalazła się również informacja o napadzie Kozaków na Warnę oraz o panice $\mathrm{z}$ tego powodu w stolicy tureckiej, którą zamknięto na trzy dni po tym wydarzeniu?.

\section{3}

Najszersza relacja dotyczy sejmu warszawskiego z 1626 r. (27 stycznia - 10 marca). Są to dwa listy Krzysztofa Zawiszy do Jana Stanisława Sapiehy, wówczas już marszałka wielkiego litewskiego. Zawisza był w Warszawie na dwa dni przed rozpoczęciem sejmu, czyli 25 stycznia. Jednak jego pierwszy list jest datowany dopiero na 21 lutego $^{10}$, ale informował o przebiegu sejmu od jego początku. Może nawet Krzysztof robił sobie notatki, bo wymienił liczbę obecnych senatorów na początku obrad. Było ich tylko dziesięciu z kasztelanami małymi. Wśród nich hetman wielki litewski, wojewoda wileński, Leon Sapieha oraz obaj kanclerze: koronny i Albrycht Stanisław Radziwiłl ${ }^{11}$

${ }^{6}$ Posłem $\mathrm{z}$ województwa krakowskiego był Jerzy Zbaraski, z województwa sandomierskiego jego brat Krzysztof. Wbrew realiom, nuncjusz A. Diotallevi pisał 13 XI 1620 r., że Zbarascy opowiadali się za skróceniem sejmu (J. Pi etrzak, Po Cecorze..., s. 58).

${ }^{7}$ L. Sapieha do J. S. Sapiehy 27 XI 1620 r. z Warszawy, CPHAUK, F. 48, op. 1, nr 801.

${ }^{8}$ L. Sapieha do J. S. Sapiehy 30 XI 1620 r. z Warszawy, CPHAUK, F. 48, op. 1, nr 802. Istotnie prawie cała Litwa uchwaliła 8 łanowych. Jednak powiat oszmiański zadeklarował tylko 2, podobnie jak województwo mińskie, a Inflanty 4 łanowe (J. P i et r z a k, Po Cecorze..., s. 104).

${ }^{9}$ L. Sapieha do J. S. Sapiehy 30 XI 1620 r. z Warszawy, CPHAUK, F. 48, op. 1, nr 802.

${ }^{10}$ Krzysztof Zawisza do J. S. Sapiehy, marszałka w. litewskiego 21 II 1626 r. z Warszawy, CPHAUK, F. 48, op. 1, nr 834.

${ }^{11}$ Krzysztof Zawisza nie wyniemiał nazwisk i imion kanclerzy, tylko godności. Nie odnotowal, że kanclerz koronny Wacław Leszczyński był chory. Miał na uwadze zapewne podkanclerza, 
- litewski. Posłów koronnych zgromadziło się nie więcej niż dwudziestu, a litewskich nie było nawet dziesięciu ${ }^{12}$. Marszałkiem wybrano unanimi concensu Jakuba Sobieskiego - wojewodzica lubelskiego. Propozycję od tronu wygłosil biskup łucki, podkanclerz koronny Stanisław Lubieński. Dalej omówil ogólnie wota senatorskie, w których niemal wszyscy radzili przenieść wojnę do Szwecji, uchwalić podatki, ale nie mówiono, ile i jakie, poruszono sprawy mennicy i zniżenia monety. Podkanclerz prosil, aby radzono nad obroną Inflant. Po wotach marszałek upomniał się o rozdanie wakansów. Komu i jakie urzędy dano poinformował oczywiście Krzysztof swojego szwagra ${ }^{13}$.

Następnie król wyznaczył senatorów rezydentów - tych, którzy zeszłego roku nie mogli się stawić z powodu zarazy.

31 stycznia dowiedziano się w Warszawie o klęsce pod Walmujzą (16-17 stycznia) i o rozbiciu obozu litewskiego przez Szwedów. Zawisza skomentowal to powściągliwie, wszak pisal do autora tej klęski i głównego poszkodowanego, że nowina ta wszystkich srodze poturbowala. 3 lutego wojewoda wileński, hetman wielki litewski Leon Sapieha zdawał relacje o tym w izbie poselskiej. Następnego dnia wysłano do senatu posła Andrzeja Korycińskiego z prośbą, aby jeszcze przed zakończeniem sejmu hetman wielki jechał do obozu i zaciągnąl wojsko, a hetman polny, Krzysztof Radziwill aby zatrzymal swoje wojsko oraz by król pozwolił mu je powiększyć. Ponadto sugerowano, że rozproszeni żołnierze $\mathrm{z}$ obozu J. S. Sapiehy powinni się gromadzić pod regimentem hetmana polnego. Zawisza jako „domowy sługa" Sapiehów protestował przeciwko temu, grożąc nawet, że do żadnej rzeczy nie przystapi, jeśli sie tak stanie. Był jednak osamotniony, nie mial żadnego wsparcia. Przyznał, że hetman polny cieszy się wielkim poważaniem w izbie, a nasi (czyli sapieżyńscy) z powodu respektu do niego i gęby nie rozdziewają. Jedni się go boją, inni nie chcą rozgniewać. Król w odpowiedzi na to poselstwo wyjaśnil, że z ważnych przyczyn i pewnych respektów nie chce i nie może

Stanisława Lubieńskiego, biskupa łuckiego, który wygłosił propozycję od tronu, co Zawisza odnotował (J. K wak, Sejm warszawski 1626 roku, Opole 1985, s. 61).

12 Jest to bliskie informacji P. N. Żukowiczaa (Sejmova borba pravoslavnogo zapadno russkogo dvorjanstva s cerkovnoj unijnej, cz. 4, Persburg 1910, s. 44), że na rozpoczęciu sejmu nie było więcej niż 15 posłów. Wedlug innej informacji, wysłuchało propozycji 40 posłów (J. K w a k, Sejm warszawski..., s. 68).

${ }^{13}$ Kasztelanię trocką - Albrychtowi Władysławowi Radziwiłłowi (nominacja $8 \mathrm{~V} 1626 \mathrm{r}$.; Urzędnicy centralni $i$ dygnitarze Wielkiego Księstwa Litewskiego XIV-XVIII wieku. Spisy, opr. H. Lulewicz i A. Rachuba, Kórnik 1994, s. 159); wojewóztwo smoleńskie - Aleksandrowi Korwinowi Gosiewskiemu (nominacja 15 VI 1625 r., ibidem, s. 130); referendarię - wojewodzicowi witebskiemu Mikołajowi Zawiszy (nominacja 15 VI 1625 r.; ibidem, s. 173), pisarstwo wielkie - Krzysztofowi Korwinowi Gosiewskiemu (nominacja 15 VI 1625 r.; ibidem, s. 130); krajczym został Mikołaj Wiesiołowski (nominacja 31 III 1626 r.; ibidem, s. 59) a stolnikiem - książę Aleksander Radziwilt (nominacja 3 VII 1626 r.; ibidem, s. 188). Trzy $\mathrm{z}$ tych nominacji sieggają połowy minionego roku. 
przepowiadać slużby panu hetmanowi polnemu. Hetman wielki, nie mając wojska i pieniędzy, sam nie chce jechać.

Istotnie Lew Sapieha usprawiedliwiał niepowodzenia w Inflantach brakiem pieniędzy w skarbie, z którego wziął tylko 45 tys. zł, a ze swoich dołożył 100 tys. zł uzyskane za zastaw dóbr. Wyjaśnial, że dowództwo przekazal synowi, ponieważ wojsko tego żądało. W istocie wypadł dość marnie na tle swego rywala Krzysztofa Radziwiłła, kiedy w izbie odczytano jego sprawozdanie. Hetman polny przedstawil stan wojska i wydatki na nie. Zdobył sobie uznanie posłów ${ }^{14}$.

Zawisza opisuje sytuację, która przypomina odbijanie piłeczki. 5 lutego ${ }^{15}$ izba zwrócila się do króla, aby monarcha z senatem podali najlepsze sposoby obrony. W odpowiedzi usłyszeli, że powinni zrobić to sami posłowie w swojej izbie. Litwini deklarowali, że do żadnych narad nie przystąpią, póki obrona Litwy od strony Inflant nie będzie postanowiona. Następnie stracono dwa dni, nie mogąc zadecydować, o czym mają mówić, a dalej dyskutowano o obronie od Tatarów. W gniazdach macać, czy bronić się na granicach swoich.

Potem rozpatrywano egzorbitancje, $\mathrm{z}$ których wybrano dziesięc ${ }^{16}$. Zawisza skrzętnie je zanotowal, jak również odpowiedź na nie, którą posłowie usłyszeli w senacie. Nie byli usatysfakcjonowani nią, ponieważ nie chciano jej dać in scriptis. Poslowie przedstawili ponownie egzorbitancje 20 lutego, ale brak o tym informacji w omawianym tu liście Andrzeja Zawiszy, który kończy relację 21 lutego, uparcie pisząc january. Oprócz znanych i omówionych w literaturze egzorbitancji, pojawiła się w liście Andrzeja Zawiszy nowa kwestia - przydania komisarzy do urzędu podskarbiego, którą to funkcję mieliby pelnić dożywotnio. Król nie wyraził na nich zgody, tłumacząc, że nie ma takiego prawa i bylaby to szkodliwa nowość. Mogłoby to ponadto ograniczyć kompetencje innych urzędników w przyszłości. W konkluzji swej Andrzej Zawisza zapisal, że $w$ efekcie kolo poselskie było niezadowolone i wszystkie egzorbitancje znowu odesłano do recesu, nie umieszczając żadnego punktu w konstytucjach ${ }^{17}$.

Posłowie litewscy deklarowali, że do żadnych konsultacji nie przystąpią, póki nie uchwali się obrony Inflant, czyli podatków na wojsko. 19 lutego odbyła się „sesja”, czyli narada u biskupa wileńskiego, na którą przybyli wszyscy senatorowie i posłowie litewscy. Byli to: biskup wileński Eustachy Wołłowicz, wojewodowie: wileński Lew Sapieha, mścisławski Janusz Skumin Tyszkiewicz, dorpacki Mikołaj Kiszka, kasztelan wendeński Gothard Jan Tyzenhaus, kanclerz Albrycht Stanisław Radziwill, podkanclerz Paweł Stefan Sapieha, podskarbi wielki Krzysztof Naruszewicz i starosta żmudzki Hieronim

\footnotetext{
14 J. K wak, Sejm warszawski..., s. 73.

${ }^{15}$ Do końca tego listu Zawisza myli luty ze styczniem.

${ }^{16}$ Omawia je wszystkie J. K wak (Sejm warszawski.., s. 92-98).

${ }^{17}$ A. Zawisza do J. S. Sapiehy, z Pragi, b.d. III 1626 r., CPHAUK, F. 48, op. 1, nr 835.
} 
Wołłowicz ${ }^{18}$. Spodziewano się przyjazdu w nocy kasztelana wileńskiego Mikołaja Hlebowicza ${ }^{19}$. Proponowano uchwalić wojnę na „wszystkie lata" za 4 lanowe rocznie ${ }^{20}$. Ponadto zgłoszono następujący projekt liczebości armii: 3 tys. husarii, 2 tys. rajtarów, 1 tys. kozaków, 6 tys. piechoty niemieckiej i węgierskiej. Decyzji żadnej nie podjęto. Czekano na deklaracje koronne. Korona deklarowała dwa podymne, przeciwko czemu Litwa protestowała. Nową informacją jest przede wszystkim projekt dotyczący armiii ${ }^{21}$.

Hetman polny, Krzysztof Radziwilł przyjechał tydzień przed konluzją ${ }^{22}$ - odnotowal Zawisza - ale i przy nim nie zaraz o obronie Inflant obradowano. Okazał się adherentem królewskiej strony, nad ludzkie mniemanie. Uchwały podatkowe zapadly dwa dni przed konkluzją. Uchwalono 4 lanowe - tak w Koronie, jak i na Litwie - oraz inne podatki nemine contradicente. Konkluzja ${ }^{23}$ odbyła się na górze w senacie, ponieważ w izbie poselskiej na nic zgody nie bylo. Król, chociaż chory na nogę, przyszedł również do senatu i siedział do końca. Obrona stanęla unanimiter. Pozwolili senatorowie, starostowie i dzierżawcy litewscy kwartę, czyli donatywę. Sejm zakończył się o godzinie 9 lub 10 wieczorem $z$ wielkim u ludzi podziwieniem. Tym razem książę hetman polny mówił bardzo mało, tylko kilkakrotnie odezwał się krótko, deklarując dalszą służbę, chociaż inni do łaski pańskiej go uprzedzają. Zawisza pisał o skrypcie do archiwum, który nazwał prywatnq konstytucja, która ma być ,in archivo Regni", a dotyczyl on wojny z Gustawem ${ }^{24}$. Wymienił ponadto najważniejsze konstytucje. Interesujące jest omówienie konstytucji o Trybunale Radomskim. Otóż postanowiono Trybunał Radomski w Koronie i w wielkim Księstwie Litewskim w Wilnie! Jest to jeszcze jeden dowód na to, że najwyższy sąd skarbowy litewski potocznie nazywano też Trybunałem Radomskim. Nie uchwalono natomiast propozycji dotyczącej powołania komisarzy przy wojsku koronnym, gdyby miało podlegać pod regiment hetmanów litewskich. Na to król simplicitier nie pozwolit ${ }^{25}$.

Hetman polny Krzysztof Radziwilł na prywatnej audiencji u króla, po konkluzji, która trwała kwadrans, mówił o swoich pracach dla Rzeczypospolitej, o tym, że inni go do laski królewskiej uprzedzają, ale jest gotów

${ }_{18}$ J. Kwak (Sejm warszawski..., s. 78) pisze, że przybył on na początku marca.

19 J. Kwak nie wymienia obecnych na tej naradzie kasztelana wendeńskiego, kanclerza, podskarbiego i starosty żmudzkiego (Sejm warszawski..., s. 77).

${ }^{20}$ Tylko na 3 lata (loc. cit.).

${ }^{21}$ Nie wspomnial o nim autor monografii tego sejmu. Zawisza informował ponadto o drożyźnie w Warszawie, o braku śniegu, ale i o mrozach oraz o podwyższonym stanie wody na Wiśle.

${ }^{22}$ Radziwiłł przybył 27 lutego (J. Kwak, Sejm warszawski..., s. 79).

${ }^{23}$ Ibidem, s. 110-116.

${ }^{24} \mathrm{Na}$ sejmie uchwalono dwa skrypty. Jeden dotyczył zwołania sejmu nadzwyczajnego na wypadek niebezpieczeństwa tureckiego i tatarskiego oraz dyspozycji finansowych dotyczących obrony kresów południowo-wschodnich (ibidem, s. 109), drugi - wojny ze Szwecją (ibidem, s. 111).

${ }^{25}$ Nie wspomina o tym J. Kwak. 
służyć nadal. Odpowiedział mu kanclerz litewski, dziękowal Marszałek poselski Jakub Sobieski. Nie wiadomo, czy Krzysztof odszedl z zamku ukontentowany - skomentowal Zawisza. Komentarz ten miał pewnie złagodzić ból adresata, o którym $w$ Warszawie nie mówiono nic dobrego $z$ powodu porażki w Inflantach. Krzysztof Radziwiłł przy końcu konkluzji złożył rezygnację $\mathrm{z}$ dowództwa nad częścią wojsk litewskich.

Relację z sejmu zwyczajnego z $1629 \mathrm{r}^{26}$ (9 stycznia - 20 luty) zaczyna Andrzej Zawisza od stwierdzenia, że bardzo malo robiliśmy na sejmie $\mathrm{w}$ sprawie najpoważniejszej - to znaczy obrony przed Szwedami, okupującymi Prusy. 14 lutego wyznaczono deputację do obmyślenia sposobu i środków prowadzenia wojny. Była to deputacja złożona $\mathrm{z}$ ośmiu senatorów, $\mathrm{z}$ których Andrzej Zawisza wymienil $\mathrm{z}$ urzędu tylko sześciu: arcybiskupa gnieźnieńskiego Jana Wężyka, kasztelana krakowskiego Jerzego Zbaraskiego, wojewodę wileńskiego Leona Sapiehę, wojewodę brzeskiego Jakuba Szczawińskiego, wojewodę sandomierskiego Stanisława Koniecpolskiego, podkanclerzego koronnego Tomasza Zamoyskiego. Nie wymienil marszałka wielkiego koronnego Mikołaja Wolskiego oraz podskarbiego wielkiego litewskiego Krzysztofa Naruszewicza ${ }^{27}$. Do deputacji tej weszło dwudziestu poslów, spośród których do tej pory znani byli tylko Krzysztof Radziwiłł, Jakub Sobieski i Jerzy Ossoliński ${ }^{28}$. Oprócz nich, wszedl również Krzysztof Zawisza. Jego informacje są bardzo ważne i nowe, gdy chodzi o obrady tej deputacji. Pisze on, że senatorzy odwotowali, ale bardzo libertatibus nostris przeciwne podają sposoby: pogłównie szlacheckie od każdego członka rodziny po $1 \mathrm{zl}$, także od każdej posiadanej wioski po $1 \mathrm{zl}$, a każdy chłop we wsi, ile ma domostwa po $1 \mathrm{gr}$ od głowy. Drugi sposób to nova vectigalia, czyli podatek od sprzedaży i kupna płacony przez tych, którzy sprzedają i kupują. Na tę propozycję nie pozwalało całe Księstwo Litewskie. Pan krakowski, czyli Jerzy Zbaraski, na novitates sie sili, ale mu się nie powodzi, bo wszystko libertatibus contrariae. Kolejne posiedzenie tej komisji odbyło się 16 lutego.

Informacje te są ważne chociażby dlatego, że wyjaśniają kilka kwestii. Zmieniają wykreowany przez Wandę Dobrowolską ${ }^{29}$ wizerunek Jerzego Zbaraskiego jako nieprzejednanego wroga Zygmunta III i opozycjonisty - jak się wydaje - przede wszystkim dlatego, że walczył ze „świętym” hetmanem Żółkiewskim. Potrafil on zgłosić propozycje reformatorskie, nie

\footnotetext{
${ }^{26}$ K. Zawisza do J. S. Sapiehy 14 i 16 II 1629 r. z Warszawy, CPHAUK, F. 48, op. 1, nr 858, 862.

${ }^{27}$ A. Filipczak-K ocu r, Sejm zwyczajny z roku 1629, Wrocław 1979, s. 60.

${ }^{28}$ Loc. cit.

${ }^{29}$ W. D o browolska, Ksiqżęta Zbarascy w walce z hetmanem Żólkiewskim, Przemyśl 1927.
} 
licząc się z przywilejami szlacheckimi, chociaż swój prestiż budował na szlachcie. Jego projekt pobierania opłat od towarów sprzedawanych i kupowanych nie ochranial szlachty. Nie wiadomo, czy to on zaproponowal wymienione wyżej pogłówne szlachecko-chłopskie, ale wiadomo, że nie protestowal przeciwko niemu. Ponadto zrozumialy jest jego protest, kiedy uchwalono podymne ${ }^{30}$. Nie tylko dlatego, że najbardziej obciążalo ono województwa ruskie, gdzie Zbarascy mieli swoje dobra, ale przede wszystkim dlatego, że Jerzy zglosil wcześniej skuteczniejszy sposób zaspokojenia potrzeb skarbowych. Podymne zaakceptowano, ponieważ było wcześniej ściągane w królewszczyznach, zatem znane, proste w naliczaniu, nie naruszało wolności szlacheckich.

Korespondencja Andrzeja Zawiszy z okresu sejmu zwyczajnego w 1629 r. potwierdza ponadto moje wcześniejsze ustalenia ${ }^{31}$, że Krzysztof Radziwilł zjawil się po raz pierwszy $w$ izbie poselskiej 14 lutego i nie byl jeszcze dopuszczony do ucałowania ręki królewskiej. Był jednak obecny na obradach wymienionej wyżej deputacji. Nie witał się $\mathrm{z}$ wojewodą wileńskim, hetmanem Lwem Sapiehą. Wjeżdżał w asyście 100 osób „ochędożnie” odzianych, a za nim maszerowal oddzial piechoty. 16 lutego król nie „,przypuścił” go jeszcze do ucałowania ręki, czyli nie pozwolił na oficjalne powitanie, upokarzając do końca sejmu dumnego księcia.

W odniesieniu do sejmu z 1638 r. (10 marca-kwiecień) $)^{32}$ znalazłam tylko dwa listy. Pisał je Stefan Pac, wówczas podkanclerz litewski, do Kazimierza Leona Sapichy - marszałka nadwornego litewskiego ${ }^{33}$. S. Pac nie opisywał przebiegu obrad, lecz przekazywał swoją opinię na ich temat. Dokładną relacją, jak wynika $\mathrm{z}$ treści listu, zajmowali się inni, których podkanclerz nazwał sługami. W pierwszym liście Stefan Pac pisze, że minęła już połowa sejmu, a jeszcze się nie zacząl. Chodziło o wprowadzenie Kawalerii Rycerzy Niepokalanego Poczęcia Najświętszej Marii Panny, o nałożenie ceł morskich na Gdańsk oraz na inne porty w Prusach, a także o czytanie na sejmie sprawozdań z posiedzeń senatu odbytych $w$ okresie między sejmami, czyli o tak zwane senatus consulta. My zaś twardzo stoimy - pisał Pac - abyśmy

${ }^{30}$ A. Filipczak-K ocur, Sejm..., s. 81.

${ }^{11}$ A. Fili pczak-K ocu r, Próba pojednania Krzysztofa Radziwilla z Zygmuntem III na sejmie zwyczajnym w 1629 roku, Zeszyty Wyższej Szkoły Pedagogicznej w Opolu 1979, Historia XVII, s. 68.

${ }^{32}$ A. T o m a s ze k, Sejm 1638 r. w obronie szlacheckiej równości, Czasopismo Prawno-Historyczne 1987, t. XXXIX, z. 2, s. 18-31.

${ }^{33}$ Stefan Pac, podkanclerz litewski, do Kazimierza Leona Sapiehy, marszałka nadwornego, 31 marca i 1 V 1638 r., z Warszawy, CPHAUK, F. 48, op. 1, nr 888, 889. 
sie in istam securitatem sprawowania sie o nasze rady nie poddali. Pana Boga $w$ te dni święte prosić będziemy, aby nam dal spiritum concordiae. Drugi list, datowany na dzień konkluzji, zawiera ocenę obrad. Gdyby dzieje tego sejmu opisać, trzeba by - zdaniem Paca - nie tylko arkusza papieru, ale skóry wołowej, a $\mathrm{i}$ tej byłoby za mało. Pisal to jako uczestnik 33 sejmów, na których takich cudów nie widzial. Sejm trwał osiem tygodni, z czego dwa tygodnie koło poselskie zasiadało $\mathrm{z}$ królem i senatem. Każdego dnia $w$ tych dwu tygodniach sejm konal, czesściq, iz prolongować nie chciano, a przecie prolongowano, aż też na koniec wysiedziawszy dzień caly $z$ nocq $w$ okrutnych halasach i swarach, skleciliśmy go jakokolwiek - zanotował S. Pac. Króla nie było na konkluzji; już kilka dni przedtem zachorował i nie pokazywał się w senacie. Posłowie pożegnali go leżącego w pokoju w łóżku. Nie było to jednak koniec dyskusji, ponieważ niektórzy z uczestników jeszcze „,halasowali" przez trzy dni u kanclerza koronnego Piotra Gembickiego, a czwarty dzień u podskarbiego koronnego Jana Mikolaja Daniłowicza. Przedłużyło to termin druku konstytucji i wyslania ich do kancelarii grodzich. $\mathrm{Na}$ koniec S. Pac wyraził życzenie, aby w przyszłości sejmy nie odbywały się w taki sposób.

Nie sposób przecenić korespondencji prywatnej w badaniach dziejów pierwszej Rzeczypospolitej, w tym i dziejów staropolskiego parlamentaryzmu. W omawianym tu wycinkowo zespole znajduje się mnóstwo informacji na temat zjazdów szlacheckich odbytych przed sejmami i po nich, zatem nie jest możliwe zaprezentowanie ich $\mathrm{w}$ całości. Pozwolę sobie tylko na kilka uwag uzupełniających.

\section{6}

Konwokacja w 1615 r. odbyła się w dniach 21 maja - 5 czerwca, po niedoszłym sejmie na początku roku, a uprzedzające ją sejmiki - w nietypowym terminie, jak pisze Andrzej Rachuba - 23 kwietnia. Polączono je z sejmikami relacyjnymi ${ }^{34}$. Następnego dnia prosił podkanclerzy litewski Eustachy Wolłowicz Leona Sapiehę - kanclerza wielkiego litewskiego, aby napisał instrukcję na zjazd glówny, wziąwszy pod uwagę nastroje szlachty na sejmikach, zwłaszcza tych, które zwykle sprawiały trudności. Oczywiście Wołłowicz nie mógł jeszcze znać uchwal sejmikowych. Wysłal listy do senatorów na ręce kanclerza, aby L. Sapieha przekazal je odpowiednim osobom według własnego uznania. Prosił także o korespondencje do urzędników. Decyzja o zwołaniu konwokacji była wiadoma szlachcie jeszcze przed sejmikami ${ }^{35}$. Krzysztof Radziwilł nie byl na sejmiku z powodu

${ }^{34} \mathrm{~A} . \mathrm{R}$ a c h u b a, Wielkie Ksiestwo Litewskie $w$ systemie parlamentarnym Rzeczypospolitej $w$ latach 1569-1763, Warszawa 2002, s. 261-262.

${ }^{35}$ Eustachy Wołlowicz do Leona Sapiehy 24 IV 1615 r. z Warszawy, CPHAUK, F. 48, op. 1 , nr 574. 
złego stanu zdrowia, ale na konwokację został wybrany ${ }^{36}$, wziął w niej udział i przewodniczył izbie poselskiej ${ }^{37}$. Instrukcje napisał L. Sapieha. Królowi podobała się we wszystkim ${ }^{38}$. W 1617 r. zaniedbano korespondencji do urzędników i dygnitarzy przed sejmikami oraz sejmikiem generalnym, i dlatego skarżył się Eustachy Wołłowicz, że im tylko przez uniwersaly jako Tatarom sejmiki $i$ zjazd glówny zlożono". Nazwy „konwokacja” i ,zjazd główny" używano zamiennie nawet $\mathrm{w}$ tym samym liście. Ostatnia konwokacja za rządów Zygmunta III odbyła się w 1624 r., mimo już wyraźnej niechęci szlachty do tej formy obrad ${ }^{40}$. Eustachy Wołłowicz, chociaż określił ją jako nieprawnq, to uważał, że co na sejmie nie stanęlo, wszak nam tego konwokacja naprawić, a na jedno się zgodzićt ${ }^{41}$.

Informacji o sejmikach $w$ omawianej korespondencji jest wiele; skala ich ważności rozległa. Ograniczę się tu do ważniejszych. Należy do nich niewątpliwie relacja Jarosza Wołłowicza - podskarbiego wielkiego litewskiego ${ }^{42}$, o sejmiku gromnicznym (2 luty) w 1612 r. powiatu upickiego. Był to równocześnie sejmik relacyjny po sejmie $\mathrm{z} 1611 \mathrm{r} .^{43}$ Uchwalono na nim trzecie lanowe; wszystkie inne podatki pozwoliła szlachta $z$ ochotq wydawać - według relacji podskarbiego. Nie przeszlo to jednak calkowicie bezkonfliktowo. „Młodsi bracia” nie chcieli zgodzić się na trzecie łanowe, ponieważ inne województwa uchwaliły tylko dwa, i „to nie razem". Istotnie, niektóre sejmiki pozwoliły na wybieranie tylko po jednym lanowym rocznie. Poważny konflikt spowodowała konstytucja Poparcie wojny Moskiewskiej ${ }^{44}$. Dla wyjaśnienia problemu wydaje się celowe zacytowanie jej fragmentu: Wojewodztwo Smoleńskie, y insze niektóre zamki y prowincye, z rakk nieprzyjacielskich rekuperowaliśmy, tedy one wedlug przysiegi y powinności naszey Krolewskiej, Rzpltey iako wlasność dodaiemy, co szerzey osobne diploma od Nas Rzpltej dane wyraża. Litwini oburzali się na to, że ziemia siewierska miała przypaść

${ }^{36}$ K. Radziwilt, hetman polny litewski, do L. Sapiehy 1 V 1615 r. z Wilna, CPHAUK, F. 48, op. $1, \mathrm{nr} 575$.

${ }^{37}$ A. R a chu ba, Wielkie Ksiestwo..., s. 262.

${ }^{38}$ E. Wołlowicz do L. Sapiehy 15 V 1615 r. z Warszawy, CPHAUK, F. 48, op. 1, nr 577.

${ }^{39}$ E. Wołłowicz do L. Sapiehy 29 II 1617 r. z Wilna, ibidem, nr 626. Konwokacja obradowała w Wilnie 12-27 IV 1617 r., ale uprzedzające ją sejmiki odbyly się jeszcze na początku lutego (A. R a chuba, Wielkie Księstwo..., s. 262).

${ }^{40}$ A. R a chu ba, Wielkie Ksiestwo..., s. 265.

${ }^{41}$ E. Wołlowicz do L. Sapiehy z Werek 27 III 1624 r., CPHAUK, F. 48, op. 1, nr 726.

${ }^{42}$ J. Wołłowicz do L. Sapiehy z Pojezior 6 II 1612 r., CPHAUK, F. 48, op. 1, nr 487.

${ }^{43}$ Autor monografii tego sejmu, J. B y li ńsk i (Sejm z roku 1611, Wrocław 1970) nie omówil w ogóle sejmików relacyjnych. W Bibliotece Narodowej w Kijowie przechowywany jest tom kopii z XIX w. (sygn. VIII 108m/152), w którym znajduje się diariusz z 1611 r. liczący 35 stron. Tom ten zawiera ponadto wiele innych ciekawych materiałów do sejmów z czasów pierwszego Wazy na tronie polskim, m.in. do sejmów: w 1618 r., 1620 r., 1625 r., 1628 r., do sejmu elekcyjnego Władysława IV w 1635 r., 1638 r.

${ }^{44}$ Volumina legum, wyd. J. Ochryzko, t. III, Petersburg 1859 (reprint), s. 5. 
Koronie, a nie Litwie. Na sejmiku powiatu upickiego wyjaśniał szlachcie tę kwestię podskarbi Wolłowicz, broniąc kanclerza litewskiego Leona Sapiehę, który protestowal przeciwko temu w czasie konkluzji sejmowej. Kanclerz litewski przypomnial prawa Wielkiego Księstwa do Smoleńska, Nowogrodu, Pskowa, Wielkich Luk i innych miejscowości. Protestował też nazajutrz po sejmie, gdy dowiedział się, że taka właśnie konstytucja została zredagowana. Stanęło wówczas na tym, że miano to ,zmazać” w porozumieniu $\mathrm{z}$,pieczętarzmi" koronnymi. Tak się jednak nie stało. Kiedy przyszlo do podpisania niezmienionej konstytucji, L. Sapieha zaprotestował wobec króla oraz złożył stosowny protest $\mathrm{w}$ grodzie. Dokument kazal zatrzymać. W przypadku, gdyby go mimo wszystko opublikowano, przyrzekł wnieść pozew do Trybunału Wileńskiegop i na roki ziemskie. Wszystko to napisal podskarbi Jarosz Wollowicz, aby kanclerz wiedział, jak dba o jego reputacje, jako czule dbale $i$ pilno poczuwasz sie $w$ urzędzie swoim [...] na wysokiej strażnicy ojczyzny naszej. 3 XI 1611 r. król wydal dyplom, w myśl którego, nowo zdobyte terytoria przylączono do Korony ${ }^{45}$. Konstytucja następnego sejmu z $1613 \mathrm{r}^{46}$ o przyłączeniu województwa smoleńskiego do Wielkiego Księstwa zadowoliła już szlachtę litewską.

10 XI 1613 r. zjechała się szlachta na popis do Nowogródka, zgodnie $\mathrm{z}$ konstytucją sejmową ${ }^{47}$. Popis ten zamienił się $w$ jakąś demonstracje antymagnacką. Rozpoczęto go w kościele, następnie szlachecka brać wyjechała w pole, gdzie odłączyła się grupa szlachty od reszty. Zagarnąwszy chorążego, zaczęła się nad czymś naradzać. Następnie zażądała przyłączenia się wszystkich pozostałych do nich. Chciała odbyć popis tylko przed chorążym. Było wielu pijanych uczestników tego zjazdu. Kasztelan nowogródzki Samuel Wołłowicz radził się Lwa Sapiehy, jak potraktować taki despekt ${ }^{48}$.

Niniejsze rozważania mają charakter informacji archiwalnej, a nie opracowania problemów zawartych $w$ całej korespondencji. Trudno więc o oryginalne wnioski, poza jednym. Archiwa na wschód od granicy Rzeczypospolitej kryją jeszcze mnóstwo tajemnic i niespodzianek.

\footnotetext{
${ }^{45}$ Szerzej o tym: W. Polak, O Kreml i Smoleńszczyzne, Toruń 1995, s. 285.

${ }^{46} \mathrm{VI}$, t. III, s. 95-96.

${ }^{47}$ Ibidem, s. 101.

${ }^{48}$ S. Wollowicz do L. Sapiehy 11 IX 1613 r. z Nowogródka, CPHAUK, F. 48, op. 1, nr 527.
} 